\title{
Poprawa wczesnej wytrzymałości mechanicznej płaszcza cementowego powstałego z zaczynu lekkiego
}

\begin{abstract}
Stosowanie zaczynów o obniżonej gęstości warunkowane jest występowaniem w otworze wiertniczym zróżnicowanych warunków geologiczno-technicznych. Najczęściej zaczyny lekkie stosuje się w przypadku konieczności podniesienia cementu w przestrzeni pozarurowej na wyznaczoną wysokość, podczas przewiercania profilu geologicznego, w którym występują skały chłonne, do uszczelniania warstw słabo zwięzłych i sypkich, a także w czasie prowadzenia prac rekonstrukcyjnych odwiertu. Zaczyny o obniżonej gęstości otrzymuje się wskutek wprowadzenia lekkich dodatków mineralnych lub odpadowych surowców wypełniających. Niestety płaszcz cementowy uzyskany z zaczynu lekkiego wykazuje w początkowym czasie hydratacji niskie wartości parametrów mechanicznych (wytrzymałość na ściskanie, wytrzymałość na zginanie), a odpowiedniej wytrzymałości nabiera dopiero w późniejszym czasie wiązania. Stanowi to problem podczas pomiaru stanu zacementowania. W ostatnich latach coraz częściej skracany jest czas oczekiwania na pomiary geofizyczne po zatłoczeniu i związaniu cementu. Niestety pomiary po zbyt krótkim czasie wiązania zaczynu cementowego mogą skutkować niemiarodajnym obrazem CBL, RBT, na podstawie którego związanie zaczynu może być odczytane jako częściowe lub słabe mimo obecności zaczynu w przestrzeni pierścieniowej. W związku z powyższym niezbędne było podjęcie prac nad poprawą wczesnej wytrzymałości mechanicznej płaszcza cementowego powstałego z zaczynu lekkiego. W publikacji przedstawiono wyniki prac nad poprawą wczesnej wytrzymałości mechanicznej płaszcza cementowego powstałego z zaczynów o obniżonej gęstości. Nowo opracowane receptury zaczynów charakteryzują się podwyższonymi wartościami wytrzymałości na ściskanie po krótkim czasie wiązania, co przyczynia się zarówno do poprawy efektywności uszczelniania, jak też do uzyskania faktycznego (miarodajnego) obrazu stanu zacementowania podczas pomiarów geofizycznych.
\end{abstract}

Słowa kluczowe: zaczyn cementowy, płaszcz cementowy, wytrzymałość mechaniczna, wytrzymałość na ściskanie, pomiary geofizyczne.

\section{Improvement of the early mechanical strength of cement sheath formed from lightweight cement slurry}

The use of slurries with reduced density is conditioned by the occurrence of diversified geological and technical conditions in the borehole. Most often, lightweight slurries are used in the case of the need to raise the cement higher in the annular space, while drilling a geological profile in which there are absorbent rocks, or sealing weak and loose layers, as well as during the well reconstructing work. Lightweight slurries are obtained by the addition of light mineral additives or waste filler materials. Unfortunately, the cement sheath obtained from the lightweight slurries initially exhibits low values of mechanical parameters (compressive strength, bending strength) and adequate strength is obtained at a later bonding time. This is a problem during cement bond logging. In recent years, the waiting time on cement before running a cement bond log has been increasingly reducing. Unfortunately, measurements after too short binding time of cement slurry can result in an unreliable CBL and RBT logs, based on which bonding of the cement slurry can be read as partial or weak, despite the presence of cement slurry in the annular space. Therefore, it was necessary to undertake research to improve the early mechanical strength of cement sheath formed of lightweight cement slurry. This paper presents the results of research on improving the early mechanical strength of the cement sheath formed of slurries with reduced density. Newly developed cement slurry recipes are characterized by increased values of compressive strength after a short binding time, which contributes to both the improvement of sealing efficiency and to obtaining a true (reliable) reading of the cement bond logging.

Key words: cement slurry, cement sheath, mechanical strength, compressive strength, cement bong logging. 


\section{Wprowadzenie}

Uszczelnienie kolumny rur okładzinowych w otworach wykonuje się w celu odizolowania od siebie poziomów przepuszczalnych nasyconych płynami złożowymi, w celu utrzymania kolumny rur w otworze, a także dla ochrony rur przed korozją wywołaną przez ciecze złożowe i gazy [1, 3, 6]. Przestrzeń znajdująca się pomiędzy zapuszczoną do otworu kolumną rur okładzinowych a ścianą otworu wypełniana jest zaczynem cementowym, który wypiera płuczkę wiertniczą. Stosowane podczas zabiegu cementowania zaczyny cementowe można najogólniej podzielić na zaczyny o „normalnej” gęstości - około $1750 \div 1850 \mathrm{~kg} / \mathrm{m}^{3}$, zaczyny lekkie o gęstości poniżej $1750 \mathrm{~kg} / \mathrm{m}^{3}$ oraz zaczyny ciężkie, których gęstość wynosi ponad $1900 \mathrm{~kg} / \mathrm{m}^{3}$. Gęstość zaczynu cementowego dobierana jest do określonych warunków geologiczno-technicznych, które zależą między innymi od budowy geologicznej przewiercanych warstw oraz głębokości otworu [11, 14]. W dalszej części publikacji poruszona została problematyka dotycząca zaczynów o obniżonej gęstości Receptury tego rodzaju stosowane są w przypadku konieczności podniesienia cementu w przestrzeni pierścieniowej lub pozarurowej na wyznaczoną wysokość, podczas przewiercania profilu geologicznego, w którym występują skały chłonne, lub w razie konieczności uszczelniania kawern po wysadach solnych. Najczęściej jednak zaczyny cementowe o obniżonej gęstości wykorzystywane są do uszczelniania kolumn rur okładzinowych posadowionych w profilu skał słabo zwięzłych oraz poziomach produktywnych o niskim ciśnieniu złożowym, a także podczas prowadzenia prac rekonstrukcyjnych odwiertu. Typowym objawem występowania niskiego ciśnienia złożowego jest wnikanie płuczki w trakcie wiercenia bądź zaczynu cementowego podczas cementowania w przewiercaną strukturę geologiczną, spadek ciśnienia słupa tłoczonej cieczy wiertniczej w otworze i tym samym naruszenie stanu równowagi ciśnień $[8,13]$. Obniżenie przeciwciśnienia płuczki lub zaczynu cementowego na ścianie otworu lub - w krytycznym przypadku - całkowite obniżenie tego ciśnienia może skutkować obsypaniem się ściany otworu, co prowadzi do dalszych komplikacji. W przypadku stwierdzenia strefy niskiego ciśnienia złożowego i ucieczki płuczki podczas wiercenia - możliwe jest opanowanie powyższego poprzez np. zmniejszenie gęstości płuczki czy zatłoczenie blokatorów w postaci mielonych łupin orzechów, trocin, sproszkowanej gumy, folii celofanowej lub pasty przeciwdziałającej ucieczce płuczki. Natomiast w trakcie zabiegu cementowania stref niskiego ciśnienia złożowego bądź też stref chłonnych nie ma możliwości interweniowania w razie wystąpienia ucieczki zaczynu cementowego podczas jego tłoczenia. Wiąże się to z ograniczeniami wynikającymi zarówno z zaprojektowanego czasu wiązania i gęstnienia zaczynu cementowego, jak i z odpowiednio dobranego czasu całego zabiegu cemento- wania $[4,5,12]$. Dlatego też najważniejszym etapem zabiegu uszczelniania kolumny rur posadowionych $\mathrm{w}$ warstwach słabo zwięzłych lub w profilu geologicznym, w którym mogą występować skały chłonne, jest opracowanie i zastosowanie zaczynu o obniżonej gęstości. Zaczyny tego rodzaju otrzymuje się poprzez wprowadzenie w skład receptury lekkich dodatków mineralnych lub surowców wypełniających [7, 10]. Obniżenie gęstości zaczynu cementowego pozwala zmniejszyć wartość ciśnienia hydrostatycznego w czasie cementowania, co zapobiega ucieczce cementu w słabsze strefy. Należy jednak mieć na uwadze, że płaszcz cementowy otrzymany z tego rodzaju zaczynów wykazuje w początkowym czasie hydratacji (pierwsze 2 doby) niskie wartości parametrów mechanicznych (wytrzymałość na ściskanie, wytrzymałość na zginanie), a wymaganą wytrzymałość osiąga dopiero w późniejszym czasie wiązania.

Obecnie coraz częściej skracany jest czas wymagany do prowadzenia dalszych prac po cementowaniu oraz czas oczekiwania na pomiary geofizyczne po zatłoczeniu i związaniu cementu. Dyktowane jest to głównie względami ekonomicznymi oraz przyspieszeniem prac nad realizacją kolejnych etapów wiercenia otworu. Niestety wykonanie pomiarów po zbyt krótkim czasie wiązania zaczynu cementowego może skutkować niemiarodajnym obrazem CBL, RBT. W związku z tym związanie płaszcza cementowego może być odczytane jako częściowe lub słabe (rysunek 2) mimo obecności zaczynu w przestrzeni pierścieniowej. Potwierdzeniem powyższego jest zapis w wytycznych rurowania i cementowania otworów wiertniczych ${ }^{1}$, że pomiar stanu zacementowania powinien być wykonany, gdy wytrzymałość kamienia cementowego osiąga $14 \mathrm{MPa}$. Płaszcz cementowy powstały z zaczynów o obniżonej gęstości charakteryzuje się znacznie niższymi wartościami wytrzymałości na ściskanie po krótkim czasie wiązania. Dotychczas stosowane lekkie zaczyny cementowe po 24 godzinach hydratacji osiągają wartości wytrzymałości na ściskanie w zakresie od około $5 \mathrm{MPa}$ do około $8 \mathrm{MPa}^{2}[15,16]$. Firmy naftowe coraz częściej poruszają problem dotyczący interpretacji pomiarów geofizycznych, jeżeli stwierdzony zostanie brak cementu w przestrzeni pierścieniowej, mimo że po zabiegu cementowania w protokole widnieje zapis, że „cement wyszedł do wierzchu”. Wspomnieć rów-

\footnotetext{
${ }^{1}$ Wytyczne rurowania i cementowania - dokument wewnętrzny serwisów cementacyjnych.

${ }^{2}$ Wartości wytrzymałości na ściskanie dla zaczynów o gęstości około $1500 \mathrm{~kg} / \mathrm{m}^{3}$ deponowanych w temperaturze około $30^{\circ} \mathrm{C}$.

${ }^{3}$ „Cement wyszedł do wierzchu” - określenie z protokołu stanu zacementowania potwierdzające brak zaniku cementu w strefy chłonne oraz dobre uszczelnienie przestrzeni pierścieniowej lub pozarurowej.
} 
nież należy, że w płaszczu cementowym o zbyt niskiej wartości wytrzymałości na ściskanie w początkowym czasie hydratacji na skutek słabej stabilizacji górnych partii kolumny rur okładzinowych naruszeniu może ulec mikrostruktura podczas dalszych prac po cementowaniu [2, 9]. Konsekwencją takiego stanu rzeczy będzie możliwość występowania mikroprzepływów mediów gazowych w przestrzeni pierścieniowej skutkująca koniecznością wykonania kosztownego zabiegu docementowania.

Na rysunku 1 przedstawiono stan zacementowania otworu PL2. Do uszczelnienia interwału $0 \div 600 \mathrm{~m}$ zastosowano zaczyn cementowy o gęstości $1850 \mathrm{~kg} / \mathrm{m}^{3}$. Po 24 godzinach wytrzymałość na ściskanie płaszcza cementowego powstałego z tego zaczynu wynosiła $8,2 \mathrm{MPa}$, natomiast po 48 godzinach uzyskano wartość 14,4 MPa. Na podstawie odczytu cementomierza akustycznego RBT9 widoczny był bardzo dobry stan zacementowania rur okładzinowych $w$ analizowanym interwale. Zostało to zaznaczone w prawej kolumnie na rysunku 1, gdzie widoczna jest niewielka intensywność koloru niebieskiego, potwierdzająca całkowite wypełnienie przestrzeni pierścieniowej. Natomiast na rysunku 2 przedstawiono badanie stanu zacementowania otworu o zakodowanej nazwie DE1 $\mathrm{w}$ interwale $0 \div 350 \mathrm{~m}$. Do uszczelnienia tego interwału zastosowano zaczyn lekki o gęstości $1550 \mathrm{~kg} / \mathrm{m}^{3}$. Płaszcz cementowy powstały z tego zaczynu posiadał wytrzymałość na ściskanie 4,2 MPa po 24 godzinach oraz 7,6 MPa po 48 godzinach. Na podstawie analizy wskazań cementomierza akustycznego RBT stwierdzono złe związanie cementu w interwale $30 \div 160$ metrów oraz słabe, a miejscami częściowe związanie cementu w interwale 160 $\div 350$ metrów. Brak związania cementu oznaczono kolorem niebieskim na rysunku 2. Taki obraz stanu zacementowania może również świadczyć o braku cementu w przestrzeni pierścieniowej, jednak $w$ raporcie po cementowaniu stwierdzono, że: „cement wyszedł do wierzchu”. Z kolei trzeci rysunek również przedstawia stan zacementowania w otworze DE1, jednak analiza dotyczy interwału głębokości od 900 metrów do 1300 metrów, gdzie zastosowano zaczyn o normalnej gęstości, czyli $1820 \mathrm{~kg} / \mathrm{m}^{3}$. Płaszcz cementowy powstały z tego zaczynu charakteryzował się wytrzymałością na ściskanie 9,7 MPa po 24 godzinach i 15,6 MPa po 48 godzinach. Na zaznaczonej części rysunku 3 widoczne jest dobre i bardzo dobre związanie cementu według interpretacji pomiarów RBT.

Analizując powyższe wyniki interpretacji pomiarów geofizycznych, można domniemywać, że stan zacementowania podczas pomiarów RBT uzależniony jest między innymi od parametrów mechanicznych tworzącego się płaszcza cementowego w przestrzeni pierścieniowej. Na podstawie analizy

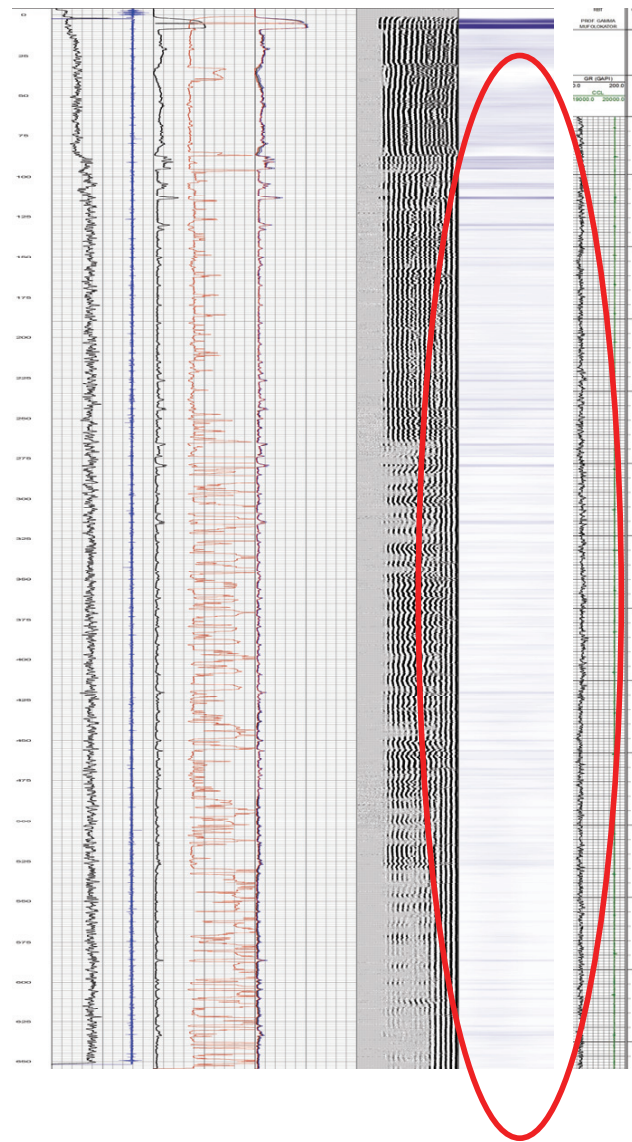

Rys. 1. Otwór PL2, interwał $0 \div 600$ metrów, zaczyn cementowy o gęstości $1850 \mathrm{~kg} / \mathrm{m}^{3}$

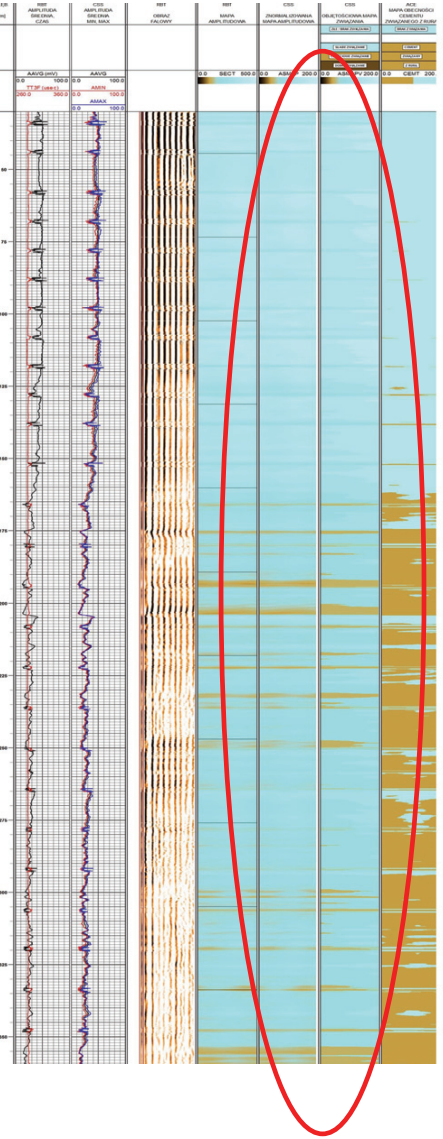

Rys. 2. Otwór DE1, interwał $0 \div 350$ metrów, zaczyn cementowy o gęstości $1550 \mathrm{~kg} / \mathrm{m}^{3}$

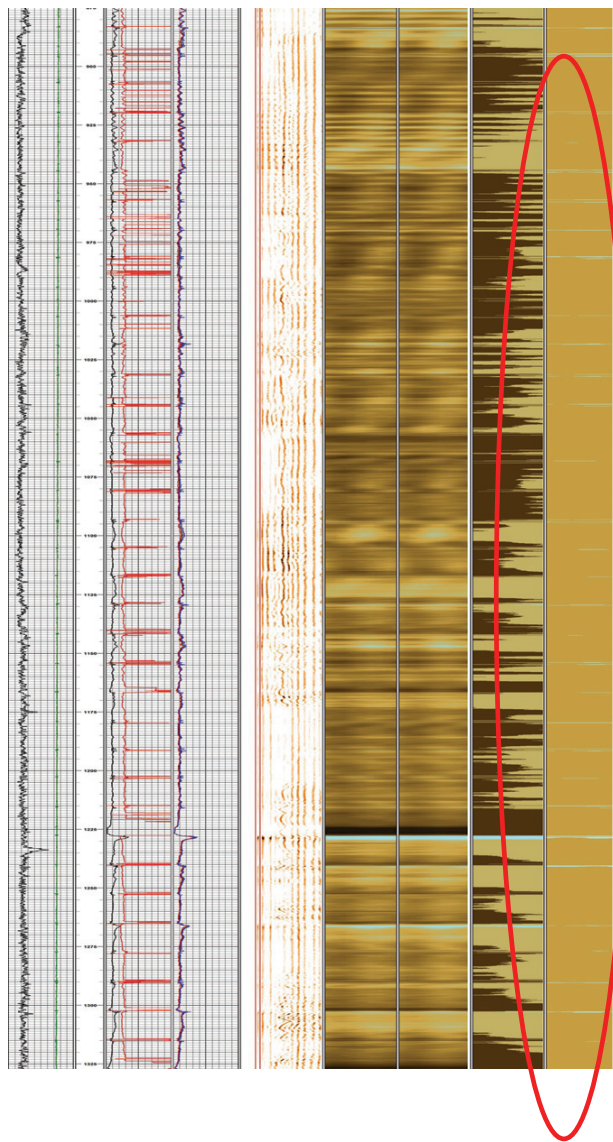

Rys. 3. Otwór DE1, interwał $900 \div 1300$ metrów, zaczyn cementowy o gęstości $1810 \mathrm{~kg} / \mathrm{m}^{3}$ 
dostępnych danych stwierdzono również, że problem podczas interpretacji stanu zacementowania występuje głównie w przypadku stosowania zaczynów lekkich, czyli na niewielkich głębokościach otworu. W związku z tym postanowiono poddać modyfikacji dotychczas używane receptury zaczynów lekkich lub opracować nowe składy zaczynów, które będą się charakteryzowały podwyższoną wytrzymałością mechaniczną już we wczesnym etapie hydratacji.

\section{Przebieg prac badawczych}

Prace badawcze nad poprawą wczesnej wytrzymałości mechanicznej płaszcza cementowego powstałego z zaczynu lekkiego przeprowadzono w Laboratorium Zaczynów Uszczelniających INiG - PIB, opierając się na normach: PN-85/G-02320 Cementy $i$ zaczyny cementowe do cementowania $w$ otworach wiertniczych; PN-EN 10426-2 Przemyst naftowy i gazowniczy. Cementy i materiaty do cementowania otworów. Część 2: Badania cementów wiertniczych oraz API SPEC 10 Specification for materials and testing for well cements.

Omówiony w dalszej części publikacji cykl badawczy polegał na wykazaniu możliwości poprawy wytrzymałości mechanicznej płaszcza cementowego w początkowym etapie hydratacji, czyli po 24 godzinach i 48 godzinach od sporządzenia zaczynu. W celu opracowania nowej receptury zaczynu zastosowano dodatki i domieszki powodujące wzrost wytrzymałości na ściskanie oraz przyspieszenie czasu wiązania zaczynu.
Trudność polegała na odpowiednim doborze zarówno jakościowym, jak i ilościowym stosowanych środków, ponieważ poprawa jednych parametrów skutkowała pogorszeniem innych, również decydujących o efektywności uszczelniania przestrzeni pierścieniowej otworu wiertniczego. W celu osiągnięcia wymaganego wzrostu wartości parametrów mechanicznych stosowano domieszki drobnocząsteczkowe, głównie na bazie krzemianów. Natomiast obniżenie gęstości zaczynu uzyskano wskutek wprowadzenia lekkich dodatków lub domieszek. Głównym badaniem było określenie gęstości zaczynu oraz pomiar wartości wytrzymałości na ściskanie w początkowym czasie hydratacji zaczynu, czyli po 24 i 48 godzinach deponowania w warunkach otworopodobnych (temperatura około $30^{\circ} \mathrm{C}$ i ciśnienie około $5 \mathrm{MPa}$ ). Następnie, po uzyskaniu wymaganych wartości, pomiarowi poddane zostały parametry technologiczne zaczynu decydujące o efektywności uszczelniania, tj.: parametry

Tablica 1. Składy wytypowanych zaczynów dla warunków otworowych o temperaturze około $30^{\circ} \mathrm{C}$ i ciśnieniu około $5 \mathrm{MPa}$

\begin{tabular}{|c|c|c|c|c|}
\hline SKŁAD & $\begin{array}{l}\text { ZACZYN } 1 \\
\text { bazowy }\end{array}$ & $\begin{array}{c}\text { ZACZYN } 2 \\
\text { wstępne modyfikacje }\end{array}$ & $\begin{array}{c}\text { ZACZYN } 3 \\
\text { nowa receptura }\end{array}$ & $\begin{array}{c}\text { ZACZYN } 4 \\
\text { zaczyn o „normalnej” } \\
\text { gęstości }\end{array}$ \\
\hline Woda wodoc. & $\mathrm{w} / \mathrm{c}=0,75$ & $\mathrm{w} / \mathrm{c}=0,65$ & $\mathrm{w} / \mathrm{c}=0,7$ & $\mathrm{w} / \mathrm{c}=0,39$ \\
\hline Bentonit (bwow) & $1,5 \%$ & $1,0 \%$ & $0,5 \%$ & - \\
\hline Środek odpieniający & $0,5 \%$ & $0,5 \%$ & - & $0,5 \%$ \\
\hline Środek upłynniający SW & $0,2 \%$ & $0,3 \%$ & - & $0,2 \%$ \\
\hline Środek upłynniający ZA & - & - & $0,2 \%{ }^{2}$ & - \\
\hline Środek antyfiltracyjny SW & $0,3 \%$ & $0,3 \%$ & - & $0,1 \%$ \\
\hline Środek antyfiltracyjny ZA & - & - & $0,55 \%{ }^{1}$ & - \\
\hline Lateks & $10,0 \%$ & $5,0 \%$ & - & $10,0 \%$ \\
\hline Stabilizator lateksu & $1,0 \%$ & $0,5 \%$ & - & $1,0 \%$ \\
\hline Środek przyspieszający czas gęstnienia & $3,5 \%$ & $3,0 \%$ & - & $1,5 \%$ \\
\hline Mikrokrzemionka & - & $10,0 \%$ & - & - \\
\hline Mikrokrzemionka SBC & - & - & $20,0 \%$ & - \\
\hline Mikrocement & $10,0 \%$ & $10,0 \%$ & $20,0 \%$ & $10,0 \%$ \\
\hline Mikrosfera & $10,0 \%$ & - & - & - \\
\hline Mikrosfera CNS & - & $15,0 \%^{1}$ & - & - \\
\hline Mikrosfera HS5 & - & - & $10,0 \%{ }^{3}$ & - \\
\hline Cement CEM G & $100,0 \%$ & $100,0 \%$ & $100,0 \%$ & $100,0 \%$ \\
\hline Dodatek spęczniający & - & $0,3 \%$ & - & $0,3 \%$ \\
\hline
\end{tabular}

${ }^{1}$ - zastosowano inny rodzaj mikrosfery niż w recepturze nr 1

${ }^{2}$ - zastosowano innego rodzaju środek upłynniający oraz antyfiltracyjny niż w pozostałych recepturach

${ }^{3}$ - zastosowano nowy rodzaj wysoko wytrzymałego środka obniżającego gęstość 
Tablica 2. Parametry badanych receptur zaczynów dla warunków otworowych o temperaturze około $30^{\circ} \mathrm{C}$ i ciśnieniu około $5 \mathrm{MPa}$

\begin{tabular}{|c|c|c|c|c|c|}
\hline \multicolumn{2}{|l|}{ Parametr } & $\begin{array}{l}\text { ZACZYN } 1 \\
\text { bazowy }\end{array}$ & $\begin{array}{c}\text { ZACZYN } 2 \\
\text { wstępne modyfikacje }\end{array}$ & $\begin{array}{c}\text { ZACZYN } 3 \\
\text { nowa receptura }\end{array}$ & $\begin{array}{c}\text { ZACZYN } 4 \\
\text { zaczyn o „,normalnej” } \\
\text { gęstości }\end{array}$ \\
\hline \multicolumn{2}{|l|}{ Gęstość $\left[\mathrm{kg} / \mathrm{m}^{3}\right]$} & 1450 & 1550 & 1450 & 1840 \\
\hline \multirow{2}{*}{ Wytrzymałość na ściskanie } & $\begin{array}{l}\text { po } 24 \text { godzi- } \\
\text { nach hydratacji }\end{array}$ & 5,4 & 9,5 & 10,3 & 8,6 \\
\hline & $\begin{array}{l}\text { po } 48 \text { godzi- } \\
\text { nach hydratacji }\end{array}$ & 7,8 & 13,6 & 14,8 & 14,4 \\
\hline \multicolumn{2}{|l|}{ Rozlewność [mm] } & 210 & 260 & 240 & 230 \\
\hline \multicolumn{2}{|l|}{ Filtracja $\left[\mathrm{cm}^{3} / 30 \mathrm{~min}\right]$} & 300,0 & 170 & 190,0 & 32,0 \\
\hline \multicolumn{2}{|l|}{ Lepkość plastyczna $[\mathrm{mPa} \cdot \mathrm{s}]$} & 67,5 & 177 & 307,0 & 108 \\
\hline \multicolumn{2}{|l|}{ Granica płynięcia [Pa] } & 8,4 & 23,0 & 15,6 & 55 \\
\hline \multicolumn{2}{|l|}{ Wytrzymałość strukturalna [Pa] } & 7,68 & 3,84 & 5,8 & 8,2 \\
\hline \multicolumn{2}{|l|}{ Odstój wody [\%] } & 0,8 & 0,2 & 0,4 & 0,0 \\
\hline \multicolumn{2}{|l|}{$\begin{array}{l}\text { Początek wiązania } \\
\text { Koniec wiązania }\end{array}$} & $\begin{array}{l}8: 15 \\
9: 20\end{array}$ & $\begin{array}{l}5: 15 \\
6: 00\end{array}$ & $\begin{array}{l}3: 15 \\
5: 30\end{array}$ & $\begin{array}{l}5: 00 \\
6: 20\end{array}$ \\
\hline \multirow{2}{*}{$\begin{array}{l}\text { Czas gęstnienia } \\
\left(\mathrm{t}=30^{\circ} \mathrm{C}^{*}, \mathrm{p}=5 \mathrm{MPa}\right) \\
{ }^{*} \text { czas dojścia do temp. } 10 \text { minut }\end{array}$} & $30 \mathrm{Bc}$ & $5: 25$ & $3: 45$ & $1: 25$ & $3: 20$ \\
\hline & $100 \mathrm{Bc}$ & $6: 40$ & $4: 20$ & $3: 10$ & 4:06 \\
\hline
\end{tabular}

reologiczne zaczynu, odstój wody, filtracja zaczynu w warunkach dynamicznych oraz czas gęstnienia w warunkach otworopodobnych. W tablicy 1 przedstawiono składy receptur zaczynów, natomiast w tablicy 2 - otrzymane parametry technologiczne zaczynów. Na potrzeby publikacji zamieszczono tylko pozytywne rezultaty przeprowadzonych prac badawczych.

W tablicy 1 zestawiono receptury zaczynów cementowych o obniżonej gęstości. Zaczyn nr 1 to receptura zaczynu dotychczas stosowanego. Recepturę tę przyjęto jako zaczyn bazowy w celu porównawczym. Zaczyn nr 2 to wstępne modyfikacje służące opracowaniu nowej receptury zaczynu lekkiego o podwyższonej wartości wczesnej wytrzymałości na ściskanie. Numerem 3 oznaczono nowo opracowaną recepturę zaczynu lekkiego, natomiast zaczyn nr 4 to zaczyn cementowy o „normalnej” gęstości, wynoszącej około $1800 \mathrm{~kg} / \mathrm{m}^{3}$. Zaczyn ten przedstawiono w tablicy dla porównania.

Analizując zestawione w tablicy 2 wyniki badań, stwierdzono porównywalne gęstości zaczynów od nr 1 do nr 3. Wytrzymałość na ściskanie płaszcza cementowego powstałego z dotychczas stosowanego zaczynu cementowego wynosiła 5,4 MPa po 24 godzinach oraz 7,8 $\mathrm{MPa}$ po 48 godzinach i były to najniższe wartości z analizowanej grupy zaczynów (rysunek 4). Zaczyn ten (pomijając niskie wartości parametrów mechanicznych) posiadał parametry technologiczne pozwalające na zastosowanie go do uszczelniania kolumny rur okładzinowych w warunkach otworowych w temperaturze około $30^{\circ} \mathrm{C}$ i ciśnieniu około $5 \mathrm{MPa}$.

Po przeprowadzeniu wstępnej modyfikacji w zaczynie nr 2, która polegała na zmianie rodzaju i ilości dodatku mikrosfery, ilości

\section{Wytrzymałość na ściskanie [MPa]}

0

10

20

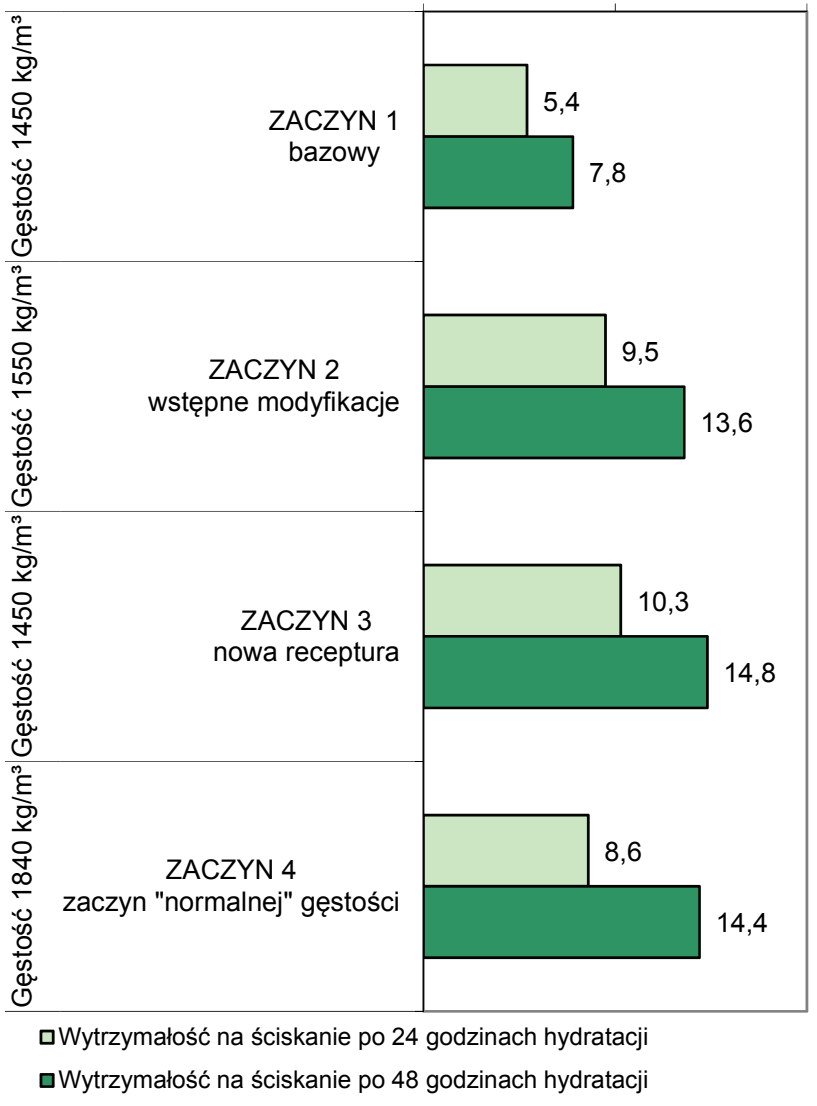

Rys. 4. Porównanie uzyskanych wartości wytrzymałości na ściskanie w zależności od gęstości zaczynu

lateksu i bentonitu oraz wprowadzeniu 10-procentowej ilości mikrokrzemionki do składu zaczynu stwierdzono widoczny na ry- 
sunku 4 wzrost wytrzymałości na ściskanie zarówno po 24 godzinach (9,5 MPa), jak i po 48 godzinach (13,6 MPa). Uzyskano również znaczne obniżenie wartości filtracji $\left(170 \mathrm{~cm}^{3} / 30 \mathrm{~min}\right)$ w porównaniu do zaczynu bazowego, w którym filtracja wynosiła $300 \mathrm{~cm}^{3} / 30 \mathrm{~min}$ (tablica 2). Czas gęstnienia uległ skróceniu, jednak nie miało to wpływu na pogorszenie parametrów technologicznych danej receptury. Niestety zmniejszenie współczynnika wodno-cementowego, obniżenie ilości lateksu oraz obecność dodatkowej ilości fazy stałej w postaci mikrokrzemionki skutkowało uzyskaniem gęstości zaczynu wynoszącej $1550 \mathrm{~kg} / \mathrm{m}^{3}$.

Receptura oznaczona numerem $3 \mathrm{w}$ tablicy 2 to nowo opracowany zaczyn lekki o gęstości $1450 \mathrm{~kg} / \mathrm{m}^{3}$. Płaszcz cementowy powstały $\mathrm{z}$ tego zaczynu wykazywał najwyższą z analizowanych wytrzymałość na ściskanie, która wynosiła 10,3 MPa po 24 godzinach oraz 14,8 MPa po 48 godzinach (rysunek 4). Przedstawiona w tablicy 1 receptura tego zaczynu charakteryzowała się niewielką ilością dodatków i domieszek. Użyto również innego rodzaju środka dyspergującego i antyfiltracyjnego niż stosowane we wcześniejszych składach. $\mathrm{Z}$ zaczynu wyeliminowano dodatek lateksu, a w celu doszczelnienia mikrostruktury płaszcza cementowego zwiększono ilość mikrocementu do wartości wynoszącej $20 \%$ (w pozostałych zaczynach: $10 \%$ ). Zastosowanie 20-procentowej ilości mikrokrzemionki SBC oraz 10-procentowej ilości nowego rodzaju wysoko wytrzymałego środka obniżającego gęstość zaczynu wywarło korzystny wpływ na wzrost parametrów mechanicznych otrzymanego płaszcza cementowego. Niestety nowo opracowany zaczyn cementowy posiadał bardzo wysokie wartości parametrów reologicznych, dużą wartość filtracji oraz czas gęstnienia wymagający wydłużenia. Jednakże na podstawie wstępnych wyników badań stwierdzono, że receptura tego zaczynu jest bardzo dobrą bazą do prowadzenia dalszych modyfikacji, których wprowadzenie skutkowało będzie uzyskaniem nieznacznej poprawy pozostałych parametrów technologicznych. Porównując parametry tego zaczynu do receptury nr 4 (tablica 2), stwierdzono wyższe wartości parametrów mechanicznych pomimo niskiej gęstości zaczynu niż w zaczynie o gęstości $1840 \mathrm{~kg} / \mathrm{m}^{3}$.

Analizując zestawiony na rysunku 5 przebieg krzywych płynięcia uzyskanych na podstawie parametrów reologicznych

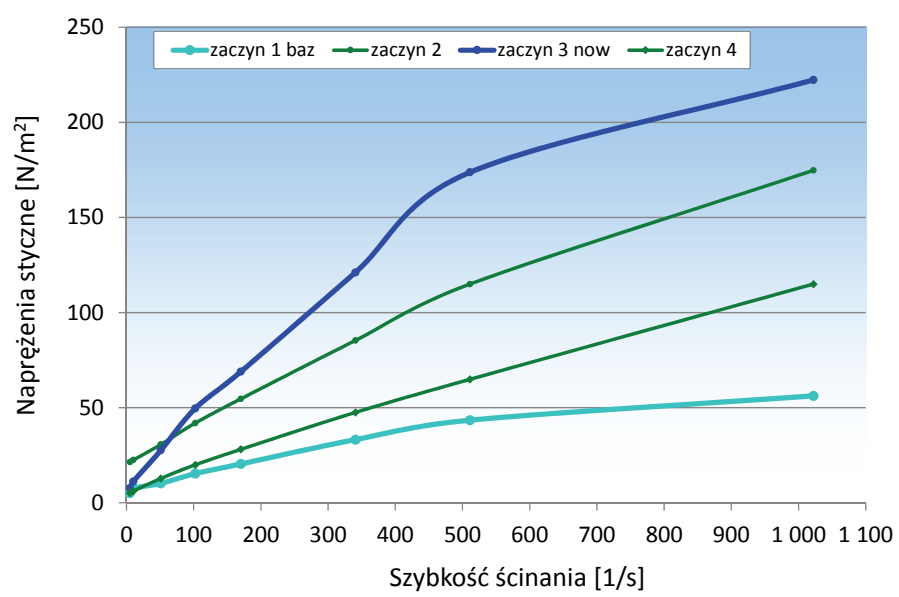

Rys. 5. Przebieg wartości krzywych płynięcia omawianych receptur zaczynów cementowych

badanych zaczynów cementowych, zaobserwowano najniższe wartości naprężeń stycznych dla dotychczas stosowanego zaczynu nr 1, którego gęstość wynosiła $1540 \mathrm{~kg} / \mathrm{m}^{3}$. Natomiast nowo opracowana receptura zaczynu nr 3 wykazywała najwyższe wartości naprężeń stycznych, co wymaga wprowadzenia modyfikacji w celu poprawy płynności zaczynu. Jednak ze względu na zawartość bardzo drobnocząsteczkowego dodatku obniżającego gęstość tego zaczynu zastosowanie większej ilości środka dyspergującego może wpłynąć na wzrost frakcjonowania dodatków w strukturze płynnego zaczynu, co należy uwzględnić podczas dalszych modyfikacji receptury zaczynu.

Należy mieć na uwadze, że omówione w niniejszej publikacji rezultaty prac badawczych to szeroki zakres wyników, które jednak w dalszym ciągu można określić mianem pilotażowych. Uzyskano założone wartości zarówno gęstości zaczynu, jak też parametrów mechanicznych. Należy jednak poczekać na końcowe rezultaty prac nad konkretną recepturą zaczynu lekkiego o wysokiej wczesnej wytrzymałości mechanicznej. W tym celu realizowane będą dalsze badania nad optymalizacją pozostałych parametrów technologicznych decydujących o efektywności uszczelniania otworu wiertniczego. W kolejnym etapie dopracowane zostaną parametry świeżego zaczynu cementowego oraz wykonane zostaną badania mikrostruktury stwardniałego zaczynu.

\section{Wnioski}

Na podstawie zrealizowanych prac badawczych sformułowano następujące wnioski końcowe:

- Zgodnie z wytycznymi rurowania i cementowania otworów wiertniczych proponuje się wykonywanie pomiarów stanu zacementowania w momencie, gdy płaszcz cementowy osiągnie wartość wytrzymałości na ściskanie wyższą lub równą $14 \mathrm{MPa}$.

- Wykonanie badań stanu zacementowania RBT w przestrzeni pierścieniowej wypełnionej zaczynem o obniżonej gęstości może skutkować niemiarodajnym obrazem stanu zacementowania. Interpretacja takiego stanu zacementowania może skutkować stwierdzeniem słabego związania cementu lub braku cementu w przestrzeni pierścieniowej lub pozarurowej.

- Poprawę interpretacji wyników pomiarów geofizycznych RBT, jak również wzrost skuteczności uszczelnienia kolumny rur podczas stosowania zaczynów lekkich można 
otrzymać między innymi poprzez zastosowanie zaczynu lekkiego o podwyższonej wczesnej wytrzymałości na ściskanie.

- W celu zwiększenia wczesnej wytrzymałości na ściskanie płaszcza cementowego z zaczynu lekkiego należy zastosować drobnoziarniste dodatki i domieszki, w których reakcje hydratacji w niskich temperaturach zachodzą szybciej niż w przypadku użycia środków o większych granulacjach.

- Zastosowanie nowego rodzaju wysoko wytrzymałego środka obniżającego gęstość zaczynu cementowego oraz dodatku drobnocząsteczkowej mikrokrzemionki przyczynia się do poprawy wczesnej wytrzymałości mechanicznej płaszcza cementowego.

- Zastosowanie nowego rodzaju mikrokrzemionki SBC oraz mikrocementu powoduje obniżenie wartości filtracji zaczynu cementowego oraz może prowadzić do zmniejszenia przepuszczalności wskutek doszczelnienia matrycy płaszcza cementowego.
- Płaszcz cementowy powstały z nowo opracowanej receptury zaczynu cementowego charakteryzuje się o ponad $90 \%$ wyższymi wartościami parametrów mechanicznych (wytrzymałość na ściskanie) niż płaszcz cementowy uzyskany z dotychczas wykorzystywanych receptur zaczynów o obniżonej gęstości.

- Zastosowanie dodatku drobnocząsteczkowych domieszek pucolanowych w celu doszczelnienia matrycy płaszcza cementowego oraz poprawy wczesnej wytrzymałości mechanicznej pozwoliło na uzyskanie oczekiwanych rezultatów, jednak spowodowało również wzrost wartości parametrów reologicznych, co wymaga wprowadzenia dodatkowych modyfikacji receptury zaczynu.

Otrzymane rezultaty prac badawczych należy traktować jako wyniki pilotażowe, które zostaną uzupełnione o dodatkowe testy laboratoryjne, pozwalające na określenie możliwości stosowania danej receptury w warunkach otworowych.

Prosimy cytować jako: Nafta-Gaz 2018, nr 8, s. 606-612, DOI: 10.18668/NG.2018.08.06

Artykuł nadesłano do Redakcji 19.06.2018 r. Zatwierdzono do druku 18.07.2018 r.

Artykuł powstał na podstawie pracy badawczej pt. Analiza możliwości poprawy wczesnej wytrzymałości mechanicznej płaszcza cementowego z zaczynów lekkich - praca INiG - PIB na zlecenie MNiSW; nr zlecenia: 14/KW/18, nr archiwalny: DK-4100/14/18.

\section{Literatura}

[1] Ciechanowska M. i in.: Ekshalacje gazu ziemnego - polskoukraiński problem Przedgórza Karpat. Analiza i ocena zagrożen ekshalacjami gazu. Kraków 2008.

[2] Dohnalik M., Zalewska J.: Korelacja wyników laboratoryjnych uzyskanych metoda rentgenowskiej mikrotomografii, jadrowego rezonansu magnetycznego i porozymetrii rtęciowej. Nafta-Gaz 2013, nr 10, s. 735-743.

[3] Gawlik P., Szymczak M.: Migracje gazowe w przestrzeniach międzyrurowych otworów realizowanych na przedgórzu Karpat. Nafta-Gaz 2006, nr 7-8, s. 349-358.

[4] Gunawan S., Fowler D.A., Mack A.: High-Performance Wellbore Displacement Spacer System. AADE-17-NTCE-067, 2017.

[5] Klaus S.R., Neubauer J., Goetz-Neunhoeffer F.: Hydration kinetics of $\mathrm{CA}_{2}$ and $\mathrm{CA}$ - Investigations performed on a synthetic calcium aluminate cement. Cement and Concrete Research 2013, vol. 43. s. 62-69.

[6] Kremieniewski M.: Ograniczenie ekshalacji gazu w otworach wiertniczych poprzez modyfikację receptur oraz ksztaltowanie się struktury stwardniałych zaczynów uszczelniajacych. Prace Instytutu Nafty i Gazu - Państwowego Instytutu Badawczego nr 199, Kraków 2016, s. 1-400.

[7] Kremieniewski M.: Poprawa stabilności sedymentacyjnej zaczynów cementowych. Prace Instytutu Nafty i Gazu - Państwowego Instytutu Badawczego nr 216, Kraków 2017, s. 1-156.

[8] Kremieniewski M., Rzepka M.: Wplyw perlitu pylistego na własności technologiczne zaczynu cementowego. Nafta-Gaz 2017, nr 12, s. 943-952, DOI: 10.18668/NG.2017.12.05.

[9] Kremieniewski M., Rzepka M.: Wodna dyspersja bezpostaciowej krzemionki jako dodatek poprawiajacy parametry technologiczne zaczynu cementowego. Nafta-Gaz 2017, nr 10, s. 750-759, DOI: 10.18668/NG.2017.10.04.
[10] Kremieniewski M., Stryczek S., Wiśniowski R., Rzepka M., Gonet A.: Influence of bentonite addition on parameters of fresh and hardened cement slurry. AGH Drilling, Oil, Gas 2017, vol. 34, nr 2, s. 335-348.

[11] Nelson E.B. i in.: Well Cementing. Schlumberger Educational Service, Houston, Teksas, USA 1990.

[12] Stryczek S. i in.: Studia nad doborem zaczynów uszczelniajacych $w$ warunkach wiercen $w$ basenie pomorskim. Wydawnictwo AGH, Kraków 2016.

[13] Stryczek S., Gonet A., Wiśniowski R.: Wpływ wybranego dodatku mineralnego na własności technologiczne zaczynów cementowych. Wiertnictwo, Nafta, Gaz 2005, t. 22/1, s. 333-341.

[14] Stryczek S., Wiśniowski R., Gonet A., Ferens W.: Parametry reologiczne świeżych zaczynów uszczelniajacych $w$ zależności od czasu ich sporzadzania. Wiertnictwo, Nafta, Gaz 2009, t. 26, z. 1-2, s. 369-382.

[15] Stryczek S., Wiśniowski R., Gonet A., Złotkowski A.: The influence of time of rheological parameters of fresh cement slurries. AGH Drilling, Oil, Gas 2014, vol. 31, s. 123-133.

[16] Wiśniowski R., Stryczek S., Skrzypaszek K.: Kierunki rozwoju badań nad reologia płynów wiertniczych. Wiertnictwo, Nafta, Gaz 2007, t. 24, z. 1, s. 595-607.

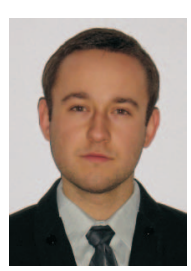

Dr inż. Marcin KREMIENIEWSKI

Adiunkt w Zakładzie Technologii Wiercenia. Instytut Nafty i Gazu - Państwowy Instytut Badawczy ul. Lubicz 25 A

31-503 Kraków

E-mail: marcin.kremieniewski@inig.pl 